\title{
Two new species of Hyphessobrycon (Teleostei: Characidae) from upper rio Tapajós basin on Chapada dos Parecis, Central Brazil
}

\author{
Tiago Pinto Carvalho and Vinicius Araújo Bertaco
}

Two new species of Hyphessobrycon are described from the upper rio Tapajós basin, Mato Grosso, Brazil. Hyphessobrycon melanostichos is distinguished from its congeners by the combination of a conspicuous longitudinal broad black band beginning on the posterior margin of orbit and reaching the tip of middle caudal fin rays, a distinct vertically elongate humeral spot, and 16 to 18 branched anal-fin rays. Hyphessobrycon notidanos is distinguished from its congeners by the combination of an elongate dorsal fin in mature males, a vertically elongate humeral spot, 2-4 maxillary teeth, iii, 8 dorsal-fin rays, and 16 to 21 branched anal-fin rays.

Duas novas espécies do gênero Hyphessobrycon são descritas para a bacia do alto rio Tapajós, Mato Grosso, Brasil. Hyphessobrycon melanostichos distingue-se de seus congêneres pela combinação da presença de uma banda preta longitudinal larga entre a margem posterior da órbita até a ponta dos raios medianos da nadadeira caudal, de uma mancha umeral verticalmente alongada, e de 16 a 18 raios ramificados na nadadeira anal. Hyphessobrycon notidanos distingue-se de seus congêneres pela combinação da presença da nadadeira dorsal alongada nos machos maduros, de uma mancha umeral verticalmente alongada, 2-4 dentes no maxilar, iii, 8 raios na nadadeira dorsal e 16 a 21 raios ramificados na nadadeira anal.

Key words: Neotropical, Characiformes, Amazon, Taxonomy, Endemism, Fish.

\section{Introduction}

Hyphessobrycon is the largest genus in the Characidae including more than one hundred valid species (Bertaco \& Carvalho, 2005a), distributed from southern Mexico to the río de La Plata in Argentina. The largest diversity is found in the Amazon basin, where approximately half of the known species occur (Costa \& Géry, 1994).

The genus was proposed by Durbin in Eigenmann (1908:100) as a subgenus of Hemigrammus Gill, differing from the latter by the absence of scales on the caudal-fin. Hyphessobrycon was extensively revised by Eigenmann $(1918,1921)$ whose account still constitutes the single comprehensive review of the genus. Several new species have been described in the last four years (Moreira et al., 2002; Lima \& Moreira, 2003; Lucena, 2003; Zarske \& Géry, 2002, 2004; Almirón et al. 2004; Bertaco \& Carvalho, 2005a; Bertaco \& Malabarba, 2005) but none of these publications discussed the relationships of the species in a cladistic perspective. Possibly, the great number and diversity of species included in Hyphessobrycon is the result of the lack of phylogenetic analyses of the species of the genus, which does not represent a single characiform clade. Instead, the current definition of the genus is noncladistic and results in the placement in Hyphessobrycon of all characid species with the combination of presumably simple characters, regardless their phylogenetic information content about relationships. A few contributions suggest the recognition of species groups, and are based primarily on similarities of color patterns and fin shape (Géry, 1961, 1966, 1977; Weitzman \& Palmer, 1997). However, as explained by Weitzman \& Palmer (1997: 210-212 \& 223-224) these features sometimes contain little information useful for phylogenetic analyses and do not necessarily present a reasonable resolution of the species level relationships in the genus.

Two new characid species were collected in July 2004 in an expedition that sampled fishes of a great number of right side bank tributaries of the Amazon, including the rio Tapajós, rio Madeira and rio Purus. While sorting the collected specimens, the streams draining into rio Juruena, a tributary of the upper rio Tapajós in the plateau of Chapada dos Parecis for-

Laboratório de Ictiologia, Museu de Ciências e Tecnologia, Pontifícia Universidade Católica do Rio Grande do Sul, Av. Ipiranga 6681, Caixa Postal 1429, 90619-900 Porto Alegre, RS, Brazil. e-mails: tiagobio2002@yahoo.com.br (TCP), ubertaco@pucrs.br (VAB) 
mation, were found to be especially diverse in number of species. Herein we comment about the great species diversity found in the upper rio Tapajós basin, indicating a previously unrecognized area of endemism. Furthermore, we conservatively describe the two new species in Hyphessobrycon according to the current definition of the genus as proposed by Eigenmann (1918).

\section{Material and Methods}

Counts were taken as described by Fink \& Weitzman (1974) with the exception of the number of scale rows below the lateral line counted from the scale row immediately ventral to the lateral line to the scale row closest to the first pelvic-fin ray. Vertebral counts, supraneurals, gill-rakers of the first arch, teeth and procurrent caudal-fin-ray counts were taken from cleared and stained specimens (c\&s) prepared according to the method of Taylor \& Van Dyke (1985). Maxillary tooth counts were taken in type specimens included in Table 1. Counts for the holotypes are indicated with an asterisk. Vertebral counts include the four vertebra integrated in the Weberian apparatus with the terminal centrum counted as one vertebra. SEM (scanning electron micrographs) pictures were taken from cleared and stained dissected specimens. Measurements were taken point to point with an electronic caliper from the left side of the specimens when possible. All measurements other than SL are expressed as a percentage of SL except subunits of the head which are recorded as a percentage of head length (HL).

Specimens examined belong to the following Brazilian institutions: MCP, Museu de Ciências e Tecnologia, Pontifícia Universidade Católica do Rio Grande do Sul, Porto Alegre; MNRJ, Museu Nacional, Rio de Janeiro, and MZUSP, Museu de Zoologia da Universidade de São Paulo, São Paulo.

\section{Hyphessobrycon melanostichos, new species}

Figs. 1-3

Holotype. MCP 39510 (34.7 mm SL, female), Brazil, Mato Grosso, Comodoro, rio Doze de Outubro on road BR 364 between Comodoro and Vilhena, 1258'39"S 6000'30"W, 14 Jul 2004, R. E. Reis, P. A. Buckup, A. R. Cardoso \& E. H. L. Pereira.

Paratypes. MCP 38396 (203, 3 c\&s, 13.0-37.3 mm SL), MZUSP 89646 (25, 13.7-34.5 mm SL), collected with the holotype.

Additional material (non types). MCP 39808 (110, 10.9-26.3 $\mathrm{mm} \mathrm{SL}$ ), collected with the holotype.

Diagnosis. Hyphessobrycon melanostichos is distinguished from all remaining species of the genus by the combination of the following characters: a conspicuous longitudinal broad black band, beginning on the posterior margin of orbit and reaching the distal tip of middle caudal fin rays; humeral spot vertically elongate and distinct from lateral band; and 16 to 18 branched anal-fin rays.

Description. Morphometric data for Hyphessobrycon melanostichos presented in Table 1. Body shape somewhat variable in a depressed to a more lozenge-shaped and deeper form; greatest body depth anterior to dorsal-fin origin. Dorsal body profile gently curved from nostril to supraocciptal spine, moderately convex from that point to dorsal-fin origin; posteroventrally declined at dorsal-fin base; straight from last dorsal-fin ray base to adipose-fin origin. Ventral profile of head convex. Ventral body profile convex from pectoral-fin origin to anal-fin origin. Body profile along anal-fin base posterodorsally inclined and gently convex. Caudal peduncle elongate, nearly straight to slightly concave along dorsal and ventral margins.

Snout convex from margin of upper lip to vertical through anterior nostrils. Head small. Mouth terminal. Posterior tip of maxilla almost reaching a vertical through middle of orbit.

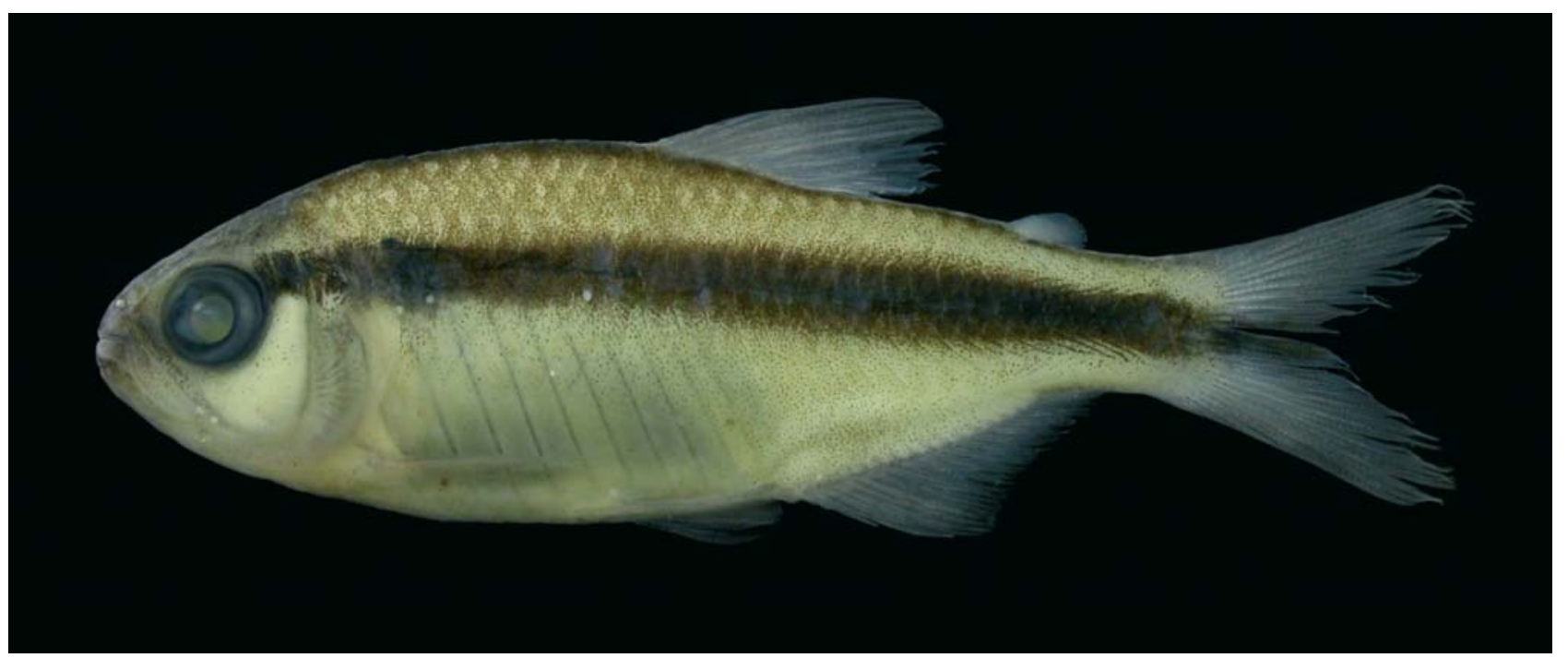

Fig. 1. Hyphessobrycon melanostichos, MCP 39510, holotype, $34.7 \mathrm{~mm} \mathrm{SL}$, female; rio Doze de Outubro, tributary of rio Juruena, rio Tapajós basin, Mato Grosso, Brazil. 


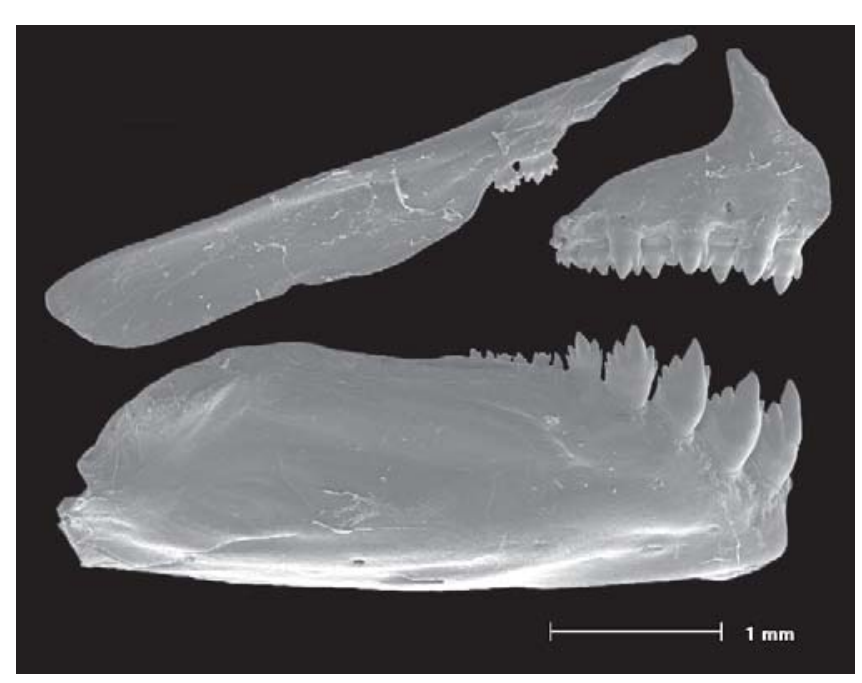

Fig. 2. Hyphessobrycon melanostichos, MCP 38396, paratype, $37.3 \mathrm{~mm}$ SL. Scanning electron microscope photograph of right side upper and lower jaws.

Maxilla positioned at approximately 45 degrees relative to longitudinal body axis. Dorsal border of maxilla nearly straight, anteroventral border concave, and posteroventral border slightly convex.

Premaxilla with two tooth rows; outer row with 2-3, tricuspid to pentacuspid teeth with central cusp larger; inner row teeth 5, gradually decreasing in length from first to fourth teeth, last tooth smaller, with 5-7 cusps and central cusp longer and broader than other cusps. One to 3 maxillary teeth, each with 3-6 cusps, central cusp slightly longer. Five anteriormost dentary teeth larger, with 5-7 cusps, followed by 5-7 smaller sized teeth with 3 cusps or conical in shape; central cusp in all teeth two to three times longer and broader than remaining cusps. Cusp tips slightly curved posteriorly and towards interior of mouth (Fig. 2).

Scales cycloid, moderately large. Lateral line incomplete, perforated scales $8-12(10 *$, mean $=10.3, \mathrm{n}=24)$. Longitudinal scale series including lateral-line scales $31-34(32 *$, mean $=$
$32.4, \mathrm{n}=22)$. Scale rows between dorsal-fin origin and lateral line 5-6 $\left(5^{*}\right.$, mean $\left.=5.4, \mathrm{n}=24\right)$; scale rows between lateral line and pelvic-fin origin $4-5$, usually $4\left(4^{*}\right.$, mean $\left.=4.1, n=24\right)$. Predorsal scales 9-11, arranged in regular series $\left(9^{*}\right.$, mean $=$ $10.1, n=24)$. Scales rows around caudal peduncle $14(n=15)$. Scale sheath along anal-fin base with 5-8 scales in single series $\left(6^{*}, n=24\right)$, extending posteriorly to base of fifth to seventh branched rays.

Dorsal-fin rays ii,9 $(n=24)$; first unbranched ray approximately one-half length of second ray, its tip reaching first bifurcation of first branched ray. Dorsal-fin origin posterior to middle of body and posterior to vertical through pelvic-fin origin. Anal-fin rays iii-iv, 16-18 $\left(16^{*}\right.$, mean $\left.=16.5, \mathrm{n}=24\right)$. Anal-fin profile slightly concave in females and gently convex to straight in males. Anal-fin origin posterior to vertical through base of last dorsal-fin ray. Pectoral-fin rays i, 10-11 $\left(11^{*}\right.$, one specimen with 9 and other with $\left.12, n=24\right)$. Change of larval pectoral-fin stage to juvenile rayed fin at about 13.1$13.7 \mathrm{~mm}$ SL. Pelvic-fin rays $\mathrm{i}, 7\left(7^{*}, \mathrm{n}=24\right)$. Pelvic-fin origin anterior to vertical through dorsal-fin origin. Caudal-fin forked, with 19 principal rays $\left(19^{*}\right.$, one specimen with $\left.18, \mathrm{n}=24\right)$. Dorsal procurrent rays 10-11 $(n=3)$. Ventral procurrent rays 9 $(n=3)$. Adipose fin present.

Precaudal vertebrae 15-16; caudal vertebrae 16-17; total vertebrae 32. Supraneurals 4 . Gill-rakers 5/11 in two specimens and $6 / 8$ in one specimen $(n=3)$.

Color in alcohol. Dorsal and dorsolateral portions of head and body dark. Infraorbitals and opercular region almost plain covered with some sparse scattered dark chromatophores. Scales of mid-dorsal row dark brown. Black longitudinal stripe from posterior margin of orbit to end of middle caudal fin rays. Longitudinal stripe broad approximately two series of scales wide, not expanded on peduncle neither reaching dorsal and ventral edges of caudal peduncle. Longitudinal stripe situated above lateral line and three scale series below dorsal-fin origin. One rounded black humeral spot below longitudinal stripe and vertically elongate, located over three to

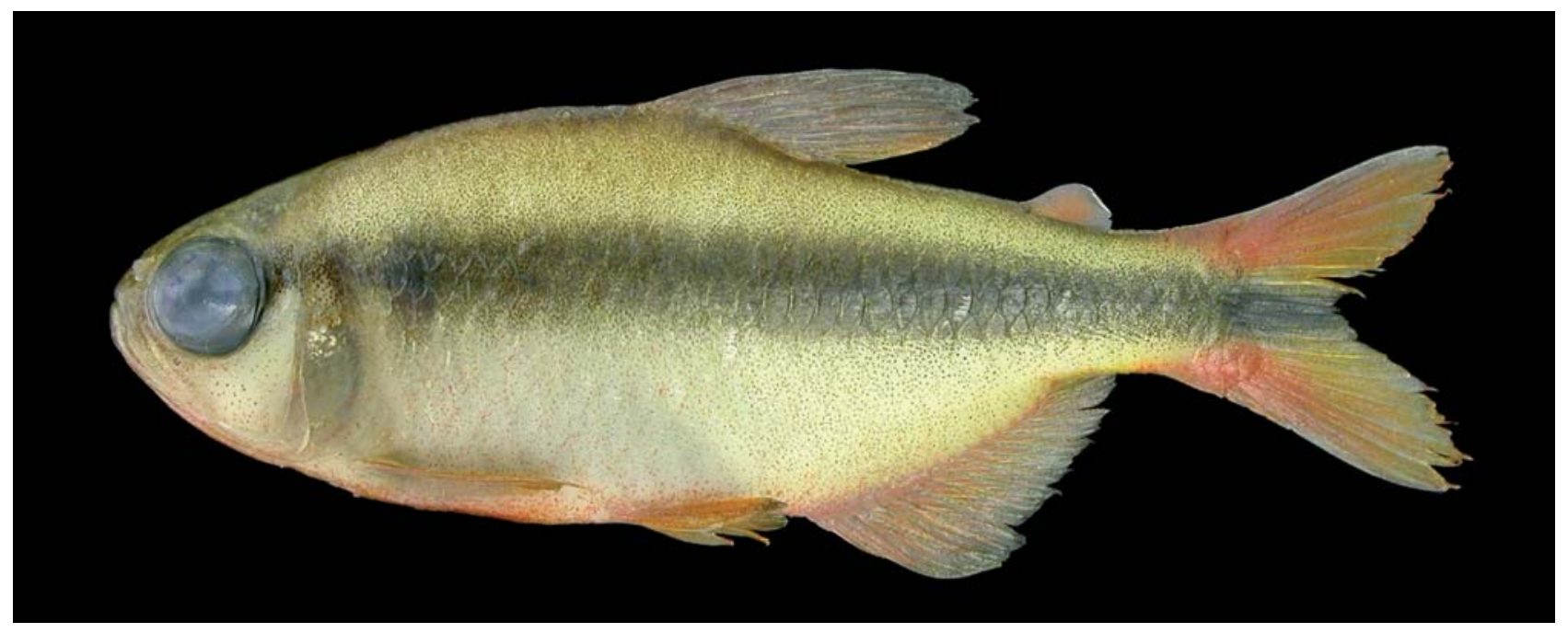

Fig. 3. Hyphessobrycon melanostichos, MCP 38396, paratype, $33.8 \mathrm{~mm}$ SL, male, color just after fixation. 
five lateral line scales and vertically extended over 3-4 horizontal series of scales, including lateral line. Five median caudal-fin rays with a dark stripe (Fig. 1). Small black chromatophores scattered over rays of all fins. Anal-fin with small black chromatophores along its distal border forming a narrow stripe in some specimens.

Color just after fixation. Color pattern similar to described for alcohol preserved specimens. One male examined soon after fixation in formalin had all fins reddish and midlateral and ventral body with scattered red pigment (Fig. 3).

Sexual dimorphism. Five paratypes were dissected (MCP 38396), including three mature males (26.1-33.8 $\mathrm{mm} \mathrm{SL}$ ) and two mature females (32.4-37.1 mm SL), but no bony hooks were observed on the fin rays. Usually males have a deeper and more lozenge-shaped body (Fig. 3), and females have a less deep and more elongate body (Fig. 1). Anal-fin profile slightly concave in females and gently convex to straight in males. Mature males lack gill gland on first gill arch.

Distribution. Hyphessobrycon melanostichos is known only from rio Doze de Outubro, a tributary of rio Juruena, in the headwaters of the rio Tapajós basin, Chapada dos Parecis, Comodoro, Mato Grosso, Brazil.

Etymology. The specific name melanostichos, from the Greek, melano a black and stichos meaning row, line. Referring to the black longitudinal stripe on the body.

\section{Hyphessobrycon notidanos, new species} Figs. 4-6

Holotype. MCP 39511 (28.6 mm SL, male), Brazil, Mato Grosso, Comodoro, rio Doze de Outubro on road BR 364 between Comodoro and Vilhena, 1258'39"S 6000'30"W, 14 Jul 2004, R. E. Reis, P. A. Buckup, A. R. Cardoso \& E. H. L. Pereira.

Paratypes. MCP 38676 (70, 3 males c\&s, 10.4-27.2 mm SL), MZUSP 89645 (15, 12.6-25.7 $\mathrm{mm} \mathrm{SL})$, collected with the holotype.

Diagnosis. Hyphessobrycon notidanos is distinguished from all remaining species currently assigned to Hyphessobrycon by the following combination of characters: dorsal fin elongate in mature males; vertically elongate humeral spot; 2-4 maxillary teeth; iii, 8 dorsal-fin rays; and 16-21 branched analfin rays. Hyphessobrycon notidanos is similar to H. loweae Costa \& Géry, 1994 but differs by number of unbranched dorsal-fin rays (iii, $8 v s$ ii,9), number of scales in lateral line series (32-34 vs 30-31), and shape of caudal peduncle spot (chromatophores present only on longitudinal axis $v s$ forming a lozenge-shaped spot).

Description. Morphometric data for Hyphessobrycon notidanos presented in Table 1. Body compressed and deep; greatest body depth anterior to dorsal-fin origin. Dorsal body profile almost straight from nostril to supraocciptal spine, convex from supraocciptal end to dorsal-fin origin; posteroventrally declined at dorsal-fin base; straight from last dorsal-fin ray to adipose-fin origin. Ventral profile of head convex. Ventral body profile also convex from pectoral-fin origin to anal-fin origin. Body profile along anal-fin base posterodorsally inclined. Caudal peduncle elongate, nearly straight to slightly concave along both dorsal and ventral margins.

Snout blunt. Head small. Mouth terminal. Maxillary tip anterior to vertical through middle of orbit, and positioned at approximately 45 degrees relative to longitudinal axis of body. Dorsal border of maxilla nearly straight, anteroventral border concave, and posteroventral border slightly convex. Maxilla slightly widened posteriorly.

Premaxilla with two tooth rows. Outer row with 2-3, tricuspid or pentacuspid teeth with central cusp larger. Inner row teeth 5 with 5-7 cusps and central cusp slightly longer and broader than other cusps; gradually decreasing in length from first to fourth teeth, last tooth considerably smaller. Two to 4 maxillary teeth, with 5-7 cusps, central cusp slightly longer. Five or six anteriormost dentary teeth larger, with 5-7 cusps, followed or not by 1-3 teeth with 2-3 cusps or conical in shape; central cusp in all dentary teeth two times longer and broader than remaining cusps. Cusp tips slightly curved posteriorly and lingually (Fig. 5).

Scales cycloid, moderately large. Lateral line incomplete, perforated scales $6-9\left(8^{*}\right.$, one specimen with 10 scales, mean $=7.4, \mathrm{n}=23$ ). Longitudinal scales series including lateral-line scales 32-34 $\left(34^{*}\right.$, mean $\left.=32.9, \mathrm{n}=23\right)$. Scale rows between dorsal-fin origin and lateral line $6(n=23)$; scale rows between lateral line and pelvic-fin origin $4(n=23)$, one specimen with 5. Predorsal scales $9-12$, arranged in regular series $\left(11^{*}\right.$, mean $=10.7, \mathrm{n}=23)$. Scales rows around caudal peduncle $14(\mathrm{n}=$ 17). Scale sheath along anal-fin base with $6-8$ scales in a single series $\left(6^{*}, \mathrm{n}=23\right)$, extending posterior to base of fifth to seventh branched rays.

Dorsal-fin elongate in males, longest rays reaching end of adipose fin base; rays iii, 8 most common count (iii, $8^{*}$, only four specimens with ii,9, $\mathrm{n}=40$ ), smaller individuals sometimes with more than 3 unbranched rays; first unbranched ray almost one-half length of second ray. Third unbranched ray longer than second; when branched the ramification begins at tip of second unbranched ray. Dorsal-fin origin approximately in middle of body and posterior to vertical through pelvic-fin origin. Anal-fin rays iii-iv, 17-20 (17*, one specimen with 16 and other with 21 , mean $=18.1, \mathrm{n}=23$ ). Anal-fin distal profile nearly straight. Anal-fin origin at vertical through base of last dorsal-fin ray. Tip of latest branched rays reaching or surpasses caudal peduncle in some specimens. Pectoral-fin rays i, $9-10\left(9^{*}\right.$, rarely 8 or 11 , mean $\left.=9.4, \mathrm{n}=23\right)$. Pelvic-fin rays i,6 $(n=23)$. Change of larval pectoral-fin stage to juvenile rayed fin at about 12.3-13.5 mm SL. Pelvic-fin origin anterior to vertical through dorsal-fin origin and almost or reaching beginning of anal fin. Caudal-fin forked, with 19 principal rays, sometimes with 18 or 20 rays $\left(19^{*}, \mathrm{n}=24\right)$. Dorsal procurrent rays $10-13(n=3)$. Ventral procurrent rays $9-12(n=$ 3). Adipose fin present. 
Table 1. Morphometric data of holotype $(\mathrm{H})$ and paratypes of Hyphessobrycon melanostichos $(\mathrm{n}=24$ including the holotype) and $H$. notidanos ( $\mathrm{n}=23$ including the holotype) from the upper rio Tapajós basin.

\begin{tabular}{|c|c|c|c|c|c|c|}
\hline & \multicolumn{3}{|c|}{ H. melanostichos } & \multicolumn{3}{|c|}{ H. notinados } \\
\hline & $\mathrm{H}$ & Range & Mean & $\mathrm{H}$ & Range & Mean \\
\hline Standard length (mm) & 34.7 & $23.1-36.2$ & 28.9 & 28.6 & $20.4-28.3$ & 24.3 \\
\hline \multicolumn{7}{|c|}{ Percents of Standard length } \\
\hline Predorsal distance & 55.6 & $52.7-58.1$ & 54.5 & 54.5 & $52.5-57.1$ & 54.9 \\
\hline Prepelvic distance & 51.6 & $49.0-53.4$ & 51.2 & 47.2 & $44.9-51.4$ & 48.3 \\
\hline Prepectoral distance & 29.7 & $27.3-32.5$ & 29.5 & 25.9 & $23.9-28.0$ & 26.1 \\
\hline Preanal distance & 68.6 & $63.6-69.9$ & 67.8 & 62.9 & $62.9-69.3$ & 65.4 \\
\hline Depth at dorsal-fin origin & 36.3 & $30.5-39.8$ & 35.0 & 40.2 & $34.8-42.0$ & 38.3 \\
\hline Caudal peduncle depth & 13.0 & $9.5-13.0$ & 11.6 & 13.3 & $11.0-14.5$ & 13.0 \\
\hline Caudal peduncle length & 11.2 & $10.2-14.3$ & 11.9 & 11.9 & $8.8-12.3$ & 10.4 \\
\hline Anal-fin base length & 24.8 & $22.4-27.0$ & 25.0 & 31.1 & $27.0-32.0$ & 29.0 \\
\hline Dorsal-fin length & 28.8 & $25.8-30.7$ & 28.3 & 40.6 & $30.1-42.0$ & 35.7 \\
\hline Pelvic-fin length & 14.4 & $14.4-18.8$ & 16.2 & 18.2 & $15.2-18.4$ & 17.0 \\
\hline Pectoral-fin length & 20.7 & $19.8-26.9$ & 22.9 & 23.8 & $20.1-25.7$ & 23.4 \\
\hline Head length & 28.2 & $26.7-32.1$ & 29.1 & 24.8 & $24.6-27.8$ & 26.4 \\
\hline \multicolumn{7}{|c|}{ Percents of Head length } \\
\hline Snout & 23.5 & $20.3-27.5$ & 24.0 & 26.8 & $20.0-27.7$ & 24.6 \\
\hline Upper jaw length & 51.0 & $44.7-52.4$ & 49.8 & 46.5 & $41.9-50.0$ & 44.7 \\
\hline Orbital diameter & 38.8 & $37.2-48.5$ & 42.1 & 43.7 & $42.9-49.1$ & 44.3 \\
\hline Interorbital width & 32.7 & $24.3-33.7$ & 29.7 & 35.2 & $31.1-35.5$ & 33.0 \\
\hline
\end{tabular}

Precaudal vertebrae 15; caudal vertebrae 17-19; total vertebrae 32-34. Supraneurals 4. Gill-rakers 6/11 $(n=3)$.

Color in alcohol. Overall body coloration pale to yellowish. Dorsal portions of head and body dark brown. Ventral, infraorbitals and opercular areas covered with scattered, dark chromatophores. One longitudinal stripe beginning at posterior orbital margin, not conspicuous at this portion, and reaching tip of median caudal-fin rays. Stripe narrow below dorsal fin and larger but quite diffuse on posterior portion of body. A light, very conspicuous, yellowish band without dark chromatophores between dorsolateral scales and longitudinal stripe. One triangular and vertically elongate black humeral spot, with dorsal portion wider. Humeral spot located over second to fifth scale of lateral line and extending vertically on that region over the scales of three longitudinal series, including lateral line. A more or less distinct rounded and horizontally elongated blotch on caudal peduncle. Small black chromatophores scattered over rays of all fins. Anal fin with small black chromatophores along its distal border forming a narrow stripe. Concentrated dark pigment on tip of pelvic fins and unbranched dorsal-fin rays in some specimens. Black pigments forming a stripe on 4-5 median caudal-fin rays (Fig. 4).

Color just after fixation. Color pattern similar to described for alcohol preserved specimens. Specimens examined soon after fixation in formalin, have all fins and body with red to yellowish pigments (Fig. 6).

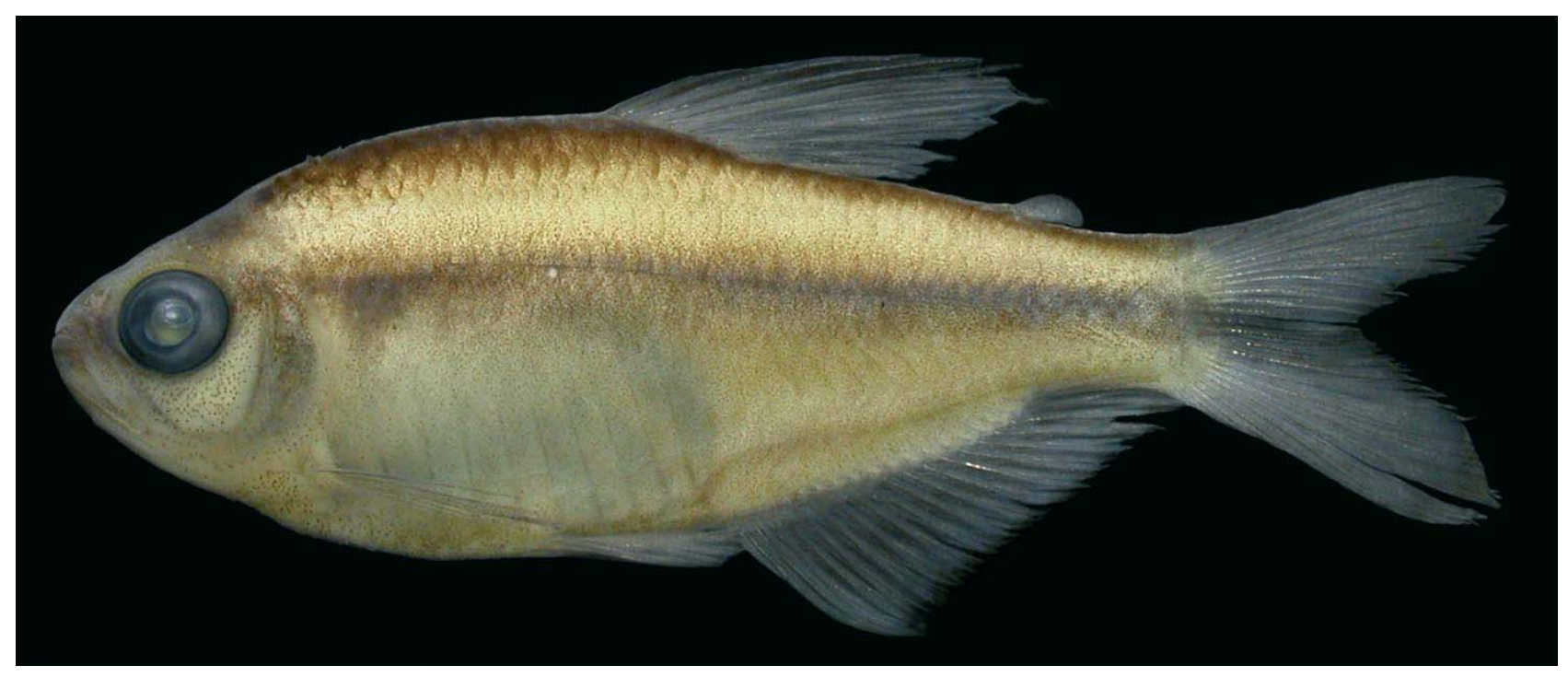

Fig. 4. Hyphessobrycon notidanos, MCP 39511, holotype, $28.6 \mathrm{~mm} \mathrm{SL}$; male, rio Doze de Outubro, tributary of rio Juruena, rio Tapajós basin, Mato Grosso, Brazil. 


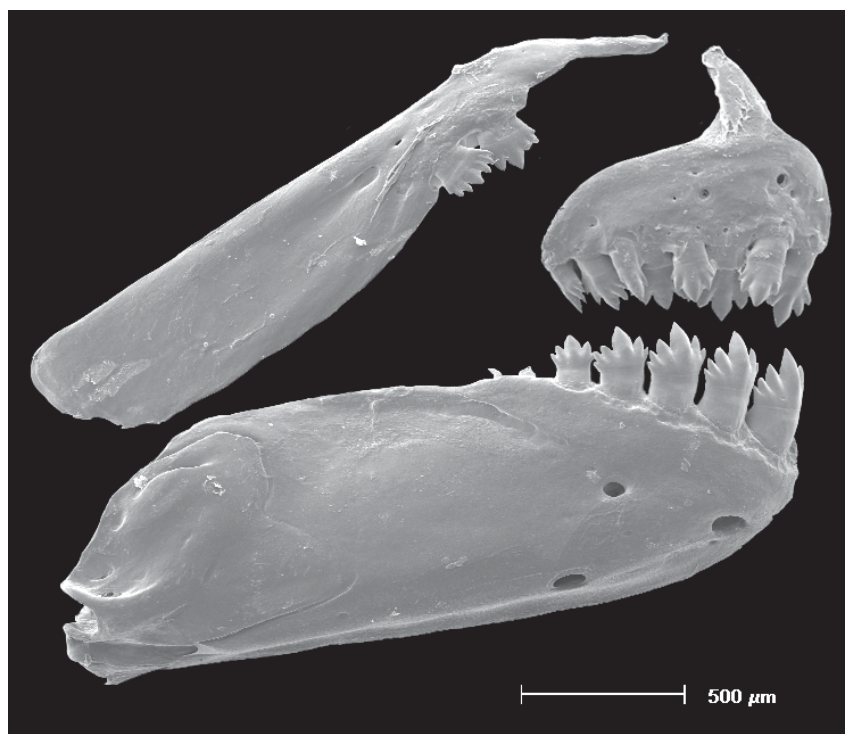

Fig. 5. Hyphessobrycon notidanos, MCP 38676, paratype, $26.3 \mathrm{~mm}$ SL. Scanning electron microscope photograph of right side upper and lower jaws.

Sexual dimorphism. Four males dissected and identified by observation of the testes. Dorsal fin elongate, reaching posteriorly to base of adipose fin. Mature males not presents gill gland on first gill arch.

Distribution. Hyphessobrycon notidanos its known only from the type locality: rio Doze de Outubro, tributary of rio Juruena, in the headwaters of the rio Tapajós basin, Chapada dos Parecis, Comodoro, Mato Grosso, Brazil.

Etymology. The name specific notidanos, from Greek, with pointed dorsal fin, referring to the elongate dorsal-fin rays in males.
Ecological notes. The type specimens of $H$. melanostichos and $H$. notidanos were collected close to the margin along semilentic stretches of a shallow river with clear water, sand and scattered small stones on the bottom, with moderately submersed and riparian vegetation. Some specimens of $H$. melanostichos (MCP 39808, 6 of 110, 13.0-26.3 mm SL) presented kyphotic lordosis. These abnormalities are similar to described in several specimens of Astyanax alburnus (Hensel, 1870) (= Cyanocharax alburnus) from the lago Guaíba, laguna dos Patos system, southern Brazil (Flores-Lopes et al., 2002), caused by infection of metacercarial cysts of digenetic trematodes in the vertebral column.

\section{Discussion}

The two new characid species are described in Hyphessobrycon according to the current definition proposed by Durbin in Eigenmann (1908), further elaborated by Eigenmann (1918), and which is still in use (Reis et al., 2003): premaxillary teeth in two rows; maxillary teeth absent or reduced in number and restricted to the upper portion of its free margin; lateral line incomplete; adipose fin present; and caudal fin not covered with scales.

Weitzman \& Malabarba (1998) pointed out that Hyphessobrycon is undoubtedly non monophyletic and perhaps approximately 60 of the 90 species, at that time, would have to be transferred to other existent or new genera. Recognition of monophyletic groups among Hyphessobrycon species is complicated by the difficulty in finding characters useful for hypothesis of relationships among the species. Weitzman \& Malabarba (1998) indicated that large characid genera such as Hyphessobrycon often have minimal morphological divergence useful for cladistic analyses of their species. Much of the information used to distinguish species are probably labile features such as variations in color patterns, counts and corporal measurements, that may be little informative about

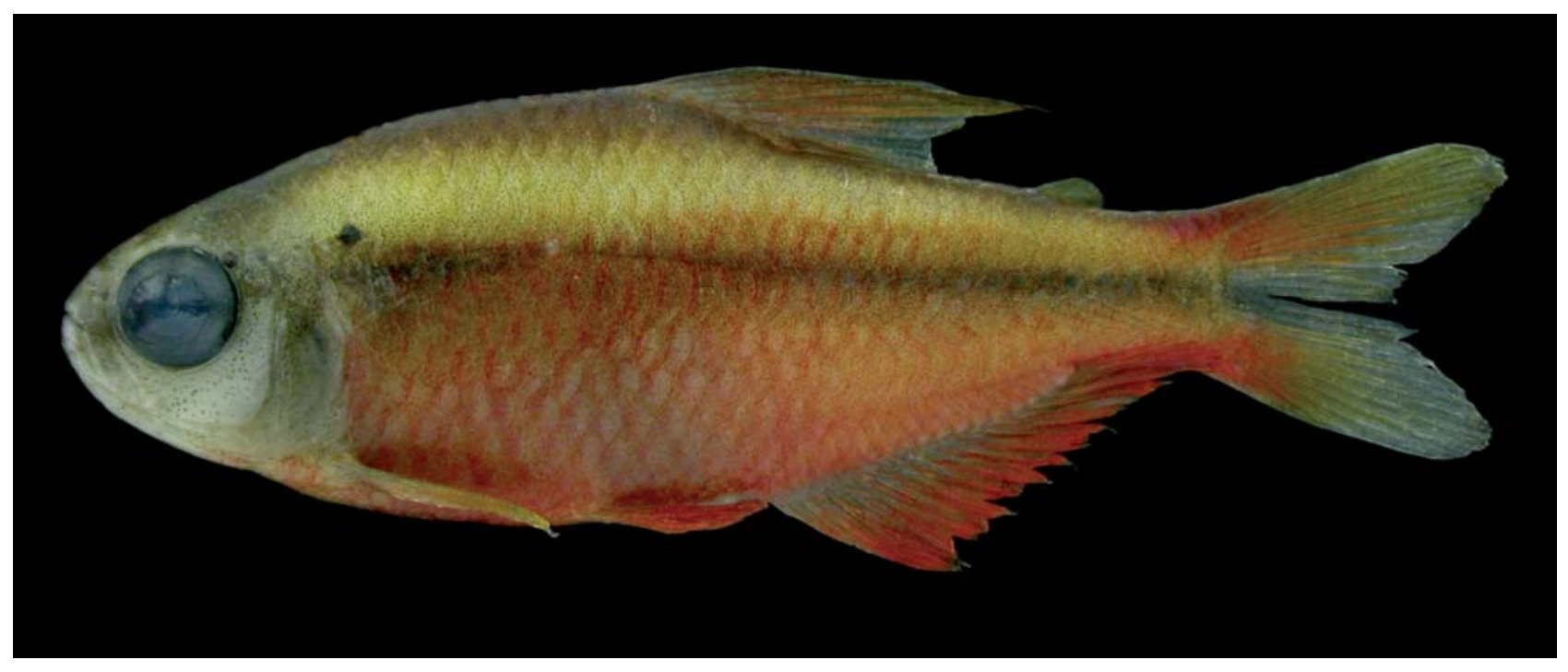

Fig. 6. Hyphessobrycon notidanos, MCP 38676, paratype, $25.7 \mathrm{~mm} \mathrm{SL}$, male, color just after fixation. 
phylogenetic relationships. Remarkably, some species of the genus present a great morphological diversity, as presented by Lima \& Moreira (2003) in the description of a heterogeneous group of three new species.

Géry (1977: 458-459), proposed six artificial groups of $H y$ phessobrycon species based on color pattern. Hyphessobrycon melanostichos and H. notidanos fit in the group of species with a "longitudinal pattern", subdivided in two subgroups that he called "heterorhabdus-group" with a narrow longitudinal band along the body axis and "agulha-group" where the band is usually not very dark but very broad. In addition to the species cited by Géry (1977) in his key, four species were subsequently described with this "longitudinal pattern": H. procerus Mahnert \& Géry, 1987; H. amapaensis Zarske \& Géry, 1998; H. nigricinctus Zarske \& Géry, 2004, and H. auca Almirón et al., 2004. However, H. notidanos differs from those species by the number of unbranched dorsalfin rays (iii, $8 v$ sii,9), and H. melanostichos differs by its conspicuous broad longitudinal band and number of anal-fin rays (see diagnosis). No other character was found that could suggest some similarity between Hyphessobrycon species we examined.

A conspicuous longitudinal dark band on the body is found in some characid fish species. Among the Tetragonopterinae (sensu Géry, 1977), it is found in Astyanax dnophos Lima \& Zuanon, A. pelecus Bertaco \& Lucena, Hemigrammus skolioplatus Bertaco \& Carvalho, Inpaichthys kerri Géry \& Junk, Knodus geryi Lima et al., Moenkhausia heikoi Géry \& Zarske, M. phaeonota Fink, Nematobrycon lacortei Weitzman \& Fink, N. palmeri Eigenmann, and Tucanoichthys tucano Géry \& Römer. However, no additional characters were found that could suggest some similarity among these taxa.

The number of unbranched dorsal-fin rays in most $\mathrm{Hy}$ phessobrycon species is usually ii, 9 , but in almost all specimens examined of $H$. notidanos it is iii,8. This pattern is shared with some specimens of $H$. weitzmaniorum Lima \& Moreira (2003), an uncommon count for the genus or even for most characid species. This unusually character could suggest a close relationship between these taxa.

The elongation of dorsal-fin rays is found in males of $H$. elachys Weitzman (1984), H. loweae, H. heliacus Moreira, Landim \& Costa (2002), and Hyphessobrycon species of the rosy tetra group of Weitzman \& Palmer (1997). The elongate dorsal-fin rays of $H$. notidanos, however, never surpass the vertical line trough the end of adipose fin, differing from the species above, in which the elongate dorsal fin reaches the caudal fin. Furthermore, H. notidanos differs from those species by color pattern.

Six Hyphessobrycon species were previously described from the rio Tapajós basin: H. pulchripinnis Ahl (1937), $H$. cachimbensis Travassos (1964), H. vilmae Géry (1966), $H$. heliacus, H. scutulatus Lucena (2003), and H. hexastichos Bertaco \& Carvalho (2005). The last four species were described from the upper portions of rio Tapajós, indicating along with the two new species described herein, an undiscovered characid fish fauna within the relatively poorly sampled rio Tapajós basin. Reports on the species composition of the basin are nonexistent (Bertaco \& Carvalho, 2005b).

During the Transcontinental Expedition (TCE) several tributaries of the rio Tapajós, rio Madeira, rio Purus and rio Paraguay basins were sampled. Hyphessobrycon melanostichos and $H$. notidanos were collected only in the rio Doze de Outubro, a tributary of the rio Juruena, upper rio Tapajós basin. The occurrence of these two new species, along with Hyphessobrycon hexastichos, Hemigrammus skolioplatus, Hasemania sp. n. Bertaco \& Malabarba (in press), Bryconamericus sp. n. J. Pezzi da Silva (pers. comm.) (Characidae); Ancistrus parecis Fisch-Muller et al. (2005); a new genus of Ancistrinae (Loricariidae) and a new species of Cetopsorhamdia (Heptapteridae) R. Reis (pers. comm.) suggest that this portion of rio Tapajós basin formed by the rivers in the Chapada dos Parecis Formation draining to rio Juruena has an apparently endemic ichthyofauna that differs from other rivers of the east bank of the Amazon or even from the rio Arinos and rio Teles Pires basins, both also tributaries of the rio Tapajós. Further extensive studies on the composition of the fish fauna will be necessary to corroborate or not the delimitation of this area of endemism.

Comparative material. (All from Brazil): Hyphessobrycon cachimbensis: MNRJ 9197, paratype, 24.8 mm SL; MNRJ 9198, paratype, $18.7 \mathrm{~mm}$ SL, Pará, rio Cachimbo, rio Tapajós basin. Hyphessobrycon cf. coelestinus: MCP 27216, 5, 24.9-27.6 mm SL, Distrito Federal, marsh affluent to lagoa Bonita, near Planaltina, upper rio Paraná basin. Hyphessobrycon elachys: MCP 10737, 22, 9.7-16.43 $\mathrm{mm} \mathrm{SL}$, Mato Grosso, pool in the road about $36 \mathrm{~km}$ from Cuiabá to Campo Grande, rio Paraguay basin. Hyphessobrycon heliacus: MCP 34551, 29, 18.8-26.5 mm SL, Mato Grosso, small stream affluent of rio do Braço, rio Tapajós basin. Hyphessobrycon heterorhabdus: MCP 23424, 10, 20.1-23.5 mm SL, Pará, Igarapé about $11 \mathrm{~km}$ from São Domingos do Capim on the road BR-010, rio Amazonas basin. Hyphessobrycon hexastichos: MCP 37649, 145 paratypes, 16.9-46.8 mm SL, Mato Grosso, rio Mutum, tributary of rio Juruena, rio Tapajós basin. Hyphessobrycon pulchripinnis: MCP 32011, 1, 29.0 mm SL, Mato Grosso, rio Kaiapá, rio Tapajós basin. Hyphessobrycon scutulatus: MCP 33729, 6 paratypes, 27.4$29.1 \mathrm{~mm}$ SL, Mato Grosso, rio Kaiapá, rio Tapajós basin. Hyphessobrycon vilmae: MCP 30824, 3, 18.0-22.6 mm SL, Mato Grosso, marsh on the road, near rio Arinos in Tapurah, rio Tapajós basin. MCP 30818, 27, 18.5-22.6 mm SL, Mato Grosso, córrego Maria on the road BR-163, $23 \mathrm{~km}$ north of Sinop, rio Tapajós basin.

\section{Acknowledgments}

This paper benefited from comments and criticisms by Cristina Bührnheim and Luiz Malabarba (MCP). Thanks to José P. da Silva (MCP) for the photographs of specimens just after fixation. We are grateful to Paulo Buckup and Marcelo Britto (MNRJ) for the loan of specimens and photos of $H$. cachimbensis; Centro de Microscopia e Microanálises CEMM, PUCRS for the SEM preparations. Specimens were collected during an expedition financed by the All Catfish Species Inventory, supported by the National Science Foundation (NSF-DEB 0315963). The senior author is financially 
supported by the Conselho Nacional de Desenvolvimento Científico e Técnológico (CNPq) and the junior author is financially supported by the Coordenação de Aperfeiçoamento de Pessoal de Nível Superior (CAPES). Collecting permits were provided by Instituto Brasileiro do Meio Ambiente e dos Recursos Naturais Renováveis - IBAMA, Portaria 054/ 2004. CNPq (Proc. 476821/2003-7; Proc. 464545/00-5). Comments of two anonymous reviewers greatly improved this paper, including a suggestion for the scientific name of the first Hyphessobrycon species described herein.

\section{Literature Cited}

Almirón, A. E., J. R. Casciotta, J. A. Bechara \& F. J. Ruiz Diaz. 2004. A new species of Hyphessobrycon (Characiformes, Characidae) from the Esteros del Iberá wetlands, Argentina. Revue Suisse de Zoologie, 111 (3): 673-682.

Bertaco, V. A. \& T. P. Carvalho. 2005a. A new characid fish, Hyphessobrycon hexastichos (Characiformes: Characidae) from Chapada dos Parecis, Mato Grosso, Brazil. Neotropical Ichthyology, 3(3): 439-443.

Bertaco, V. A. \& T. P. Carvalho. 2005b. New characid fish, Hemigrammus skolioplatus (Characiformes: Characidae) from upper rio Tapajós drainage, Central Brazil. Comunicações do Museu de Ciências e Tecnologia da PUCRS, Sér. Zool., 18(2): 141-150.

Bertaco, V. A. \& L. R. Malabarba. 2005. A new species of Hyphessobrycon (Teleostei: Characidae) from the upper rio Tocantins drainage, with bony hooks on fins. Neotropical Ichthyology, 3(1): 83-88.

Bertaco, V. A. \& L. R. Malabarba. (in press). A new species of Hasemania from the upper rio Tapajós drainage, Brazil. (Teleostei: Characiformes: Characidae). Copeia.

Costa W. J. E. M. \& J. Géry. 1994. Two new species of the genus Hyphessobrycon (Characiformes: Characidae) from the rio Xingú basin, central Brazil. Revue Française d'Aquariologie, 20: 71-76.

Eigenmann, C. H. 1908. Zoological results of the Thayer Brazilian Expedition. Preliminary descriptions of new genera and species of Tetragonopterid characins. Bulletin of the Museum of Comparative Zoology, 52(6): 93-106.

Eigenmann, C. H. 1918. The American Characidae. Part 2. Memoirs of Museum of Comparative Zoology, 43: 103-208.

Eigenmann, C. H. 1921. The American Characidae. Part 3. Memoirs of Museum of Comparative Zoology, 43: 209-310.

Fink, W. L. \& S. H. Weitzman. 1974. The so-called Cheirodontin fishes of Central America with descriptions of two new species (Pisces: Characidae). Smithsonian Contributions to Zoology, 172: 1-46.

Flores-Lopes, F., L. R. Malabarba, J. F. P. Silva \& E. H. L. Pereira. 2002. Histologia de deformidades vertebrais em Astyanax alburnus (Hensel, 1870) (Ostariophysi: Characidae) do lago Guaíba, Rio Grande do Sul, Brasil. Comunicações do Museu de Ciências e Tecnologia da PUCRS, Sér. Zool., 15(1): 137-155.
Géry, J. 1961. Three new South American characids, Knodus savannensis, Hyphessobrycon herbertaxelrodi and Megalamphodus sweglesi, with a review of some Hyphessobrycon-groups of species (Contr. No. 16). Tropical Fish Hobbyist, 9(9): 26-46.

Géry, J. 1966. Hyphessobrycon vilmae sp. n., a new tetra from the upper Juruena, Brazil, with keys to the Heterorhabdus-like species. Ichthyologica/The Aquarium Journal, 63-70.

Géry, J. 1977. Characoids of the World. T.F.H. Publications, Neptune City, NJ, 672 p.

Lima, F. C. T. \& C. R. Moreira. 2003. Three new species of Hyphessobrycon (Characiformes: Characidae) from the upper rio Araguaia basin in Brazil. Neotropical Ichthyology, 1(1): 21-33.

Lucena, C. A. S. 2003. New characid fish, Hyphessobrycon scutulatus, from the rio Teles Pires drainage, upper rio Tapajós system (Ostariophysi: Characiformes: Characidae). Neotropical Ichthyology, 1(2): 93-96.

Mahnert, V. \& J. Géry. 1987. Deux nouvelles espèces du genre Hyphessobrycon (Pisces, Ostariophysi, Characidae) du Paraguay: H. guarani n. sp. et $H$. procerus n. sp. Bonner Zoologische Beiträge, 38(4): 307-314.

Moreira, C. R., F. C. T. Lima \& W. J. E. Costa. 2002. Hyphessobrycon heliacus, a new characid fish (Ostariophysi: Characiformes) from upper rio Tapajós basin, central Brazil. Copeia, 2002(2): 428-432.

Reis, R. E., S. O. Kullander \& C. J. Ferraris (Eds.). 2003. Check List of the Freshwater Fishes of South and Central America. Edipucrs, Porto Alegre, 729p.

Taylor, W. R. \& G. C. Van Dyke. 1985. Revised procedures for staining and clearing small fishes and other vertebrates for bone and cartilage study. Cybium, 9: 107-119.

Weitzman, S. H. \& L. Palmer. 1997. A new species Hyphessobrycon (Teleostei: Characidae) from the Neblina region of Venezuela and Brazil, with comments on the putative 'rosy tetra clade'. Ichthyological Exploration of Freshwaters, 7(3): 209-242.

Weitzman, S. H. \& L. R. Malabarba. 1998. Perspectives about the phylogeny and classification of the Characidae (Teleostei: Characiformes). Pp. 161-170. In: L. R. Malabarba, R. E. Reis, R. P. Vari, Z. M. S. Lucena, and C. A. S. Lucena (Eds.). Phylogeny and Classification of Neotropical Fishes. Edipucrs, Porto Alegre, $603 p$.

Zarske, A. \& J. Géry. 1998. Hyphessobrycon amapaensis spec. nov., eine neue und mutmabliche Stellvertreterart von Hyphessobrycon heterorhabdus (Ulrey, 1894) aus dem Bundesstaat Amapa in Brasilien (Teleostei: Characiformes: Characidae). Zoologische Abhandlungen, 50(1):

Zarske, A. \& J. Géry. 2002. Der Blaurote Kolumbien-Samler. Hyphessobrycon columbianus n. sp., ein neuer Samler (Teleostei, Characiformes, Characidae) aus dem Kolumbianischem Dariem. Das Aquarium, 391: 22-30.

Zarske, A. \& J. Géry. 2004. Hyphessobrycon nigricinctus sp. n. ein neuer Salmler (Teleostei: Characiformes: Characidae) aus dem Stromgebeit des río Madre de Dios in Peru. Zoologische Abhandlungen, 54: 31-38. 